\title{
What Drives Illegal Hunting with Dogs? Traditional Practice in Contemporary South Africa
}

\author{
Jaime Chambers ${ }^{1 *}$ \\ ${ }^{1}$ Department of Anthropology, Washington State University, Pullman, USA. \\ *jaime.chambers@wsu.edu
}

\begin{abstract}
Illegal hunting with dogs in rural South Africa converges around issues of conservation, resource use, and livelihood. Hunting with dogs has a long cultural history, tethered to tradition and subsistence. Today, it is tightly regula ted but practiced outside the law. Academic literature and mainstream media alike paint a multidimensional picture of the phenomenon. Some sources portray disenfranchised people practicing a culturally significant livelihood strategy; others emphasize illegal hunting's destructive nature, severed from traditional context. The drivers of illegal hunting in rural South Africa sit at the nexus of multiple gaps of scholarly insight, linked to a history of widespread stratification of land use, prohibition of traditional hunting, and systematic control of African possession of dogs. There is a need for ethnographic work rooted in environmental history to grapple with the complex connections underlying this issue.
\end{abstract}

Received August 31, 2019

OPEN ठACCESS

Accepted April 17, 2020

Published May 11, 2020

DOI 10.14237/ebl.11.1.2020.1645

Keywords Hunting, Dogs, Wildlife conservation, Illegal hunting, South Africa

Copyright (C) 2020 by the author(s); licensee Society of Ethnobiology. This is an open-access article distributed under the terms of the Creative Commons Attribution-NonCommercial 4.0 International Public License (https://creativecommons.org/licenses/by-nc/4.0), which permits non-commercial use, distribution, and reproduction in any medium, provided the original author and source are credited.

\section{Introduction}

Hunting with dogs has a long history in South Africa, tethered to tradition and subsistence. Although tightly regulated, today it is practiced outside the law, fueling conflict between rural communities, game reserves, and private landowners. Academic literature and mainstream media paint a multidimensional picture of the practice. Some sources stress the cultural and economic significance of hunting with dogs, linked to livelihood and tradition (Dlamini 2005; Hebinck 2018). Others emphasize its uncontrolled, inefficient nature, contributing to the decline of key species such as oribi (Ourebia ourebi) and serval (Leptailurus serval) (Couzens 2007:29; Grey-Ross et al. 2010; Manqele et al. 2018). Destructiveness is particularly associated with taxi hunters - a term for hunters rumored to transport dogs in minibus taxis, release them illegally on private land in pursuit of wildlife, and place bets on the outcome. In a thicket of competing narratives surrounding illegal hunting, the current gaps call for ethnographic work rooted in environmental history to answer foundational questions: who hunts with dogs illegally, and why do they do it?
Power, Tradition, and Dog Taxes: A Brief History of Hunting with Dogs in South Africa Illegal hunting with dogs occurs in a context of systematic removal of hunting rights. Restriction of traditional hunting in South Africa began by the late nineteenth century, with dogs positioned at the center of those measures. In 1891, tools such as nets, springs, snares, traps, and sticks were banned in modern-day KwaZulu-Natal, and the Game Ordinance of 1912 prohibited black South Africans from hunting with dogs (Couzens and Blackmore 2010:313). Systematic control of dogs owned by black South Africans first occurred in the 1880s, via taxation and mass extermination. Culling of dogs continued in waves throughout the twentieth century, intensifying with apartheid and the resurgence of rabies in southern Africa in the 1960s (Couzens and Blackmore 2010:311; Tropp 2002:466; Van Sittert and Swart 2008:26-27). These measures fit within broader patterns of oppression and dispossession, feeding cycles of conflict and retaliation for over a century. Contemporary illegal hunting is an heir to this history. 
Today, South African national and provincial legislation restricts traditional hunting with dogs directly and indirectly; however, the extent of this control varies by province. KwaZulu-Natal provides a useful case study, as a 1999 amendment to the KwaZulu-Natal Nature Conservation Ordinance overturned the province's outright ban, allowing traditional hunts with paid permits (Couzens and Blackmore 2010:320-321). The law defines traditional hunters as "a person, on foot, who hunts an animal using a dog or a traditional weapon, but not by means of a firearm" (KwaZulu-Natal Conservation Management Amendment Act, Section 1). Traditional hunts require a paid permit, valid for a single day in a specified place. Current law does not actively ban hunting with dogs, but legal routes involve a relatively complex set of requirements logistically and financially inaccessible to the average rural black South African. Academic literature portrays conflicting narratives about the nature of illegal hunting, but recent regulation fails to deter the practice, regardless of its form and participants.

\section{Game Farms, Dispossession, and the Specter of} the Taxi Hunter

The narratives around illegal hunting abound; however, some themes demand closer attention. Grey -Ross et al. (2010:46-47) specifically probe the taxi hunting narrative in rural settlements where $82 \%$ of surveyed men reported hunting illegally. Landowners believed gambling and sport to be the primary reason (43\%), but hunters themselves reported doing so mostly for meat $(42 \%)$ or meat in combination with skins $(8 \%)$. Communities where illegal hunting occurs share high rates of unemployment, ranging from 6688\% (Grey-Ross et al. 2010; Kaschula and Shackleton 2009). Unemployment and limited protein access represent community-wide challenges in Manqele et al.'s (2018:11) study in KwaZulu-Natal, where hunters reported consuming any prey captured. However, these authors posit that age is the most significant factor in illegal hunting with dogs, suggesting it may be practiced primarily "for sport by young men, possibly with little else to occupy their time" (Manqele et al. 2018:14). In uMkhuze, iMfolozi, and Hluhluwe game reserves, observers claim most illegal dog hunting is practiced by "disaffected youths seeking entertainment rather than sustenance" (Couzens 2007:29).

However, both sources explicitly distinguish taxi hunting as a phenomenon conducted by non-locals, separate from hunting by rural community members. This contrast suggests multi-layered participation in illegal hunting, with different forms involving local and transient actors. South Africa's drift toward urbanization has not been unilateral; rather, the actual movement of people between the urban and the rural ebbs and flows (Couzens 2007). The potential distinction between local hunters (rural boys and men) and non-local hunters (taxi hunters) points to the need for research on movement between urban and rural spaces.

Illegal hunting on privately owned game farms occurs at rates eight times higher than in game reserves (Manqele 2018:7). Increased privatization of wildlife and the proliferation of game farms postapartheid has heightened the sense of distance between those with and without legal access to hunting (Holmes 2007; 't Sas-Rolfes 2017). The perception of traditional hunters with dogs as illegitimate interlopers on a private resource perpetuates an idea with century-deep roots: "only hunting with a rifle on privately owned land, hunting privately owned game, is considered ethical and legal" (Pasmans and Hebinck 2017:447). Despite claims that game farms reduce rural unemployment, some scholars argue they provide fewer job opportunities than ecotourism or traditional farming, while destabilizing regional and national food security, foreignizing land ownership, and stripping local smallholders of access to water and grazing land (Pasmans and Hebinck 2017; Snijders 2012). In rural KwaZulu-Natal, villagers pool money to pay bail and fines for neighbors caught hunting illegally, offering community-level support in the form of "poachers' relief funds" (Warchol and Johnson 2009:150). These issues tap into themes that demand further investigation: divergent perceptions of how wildlife is to be used (or not used) and by whom, in a system of stratified resource access.

\section{Toward an Ethnographic Approach}

Ethnographic studies of illegal hunters' motivations are scarce. In surveys conducted in rural communities, local men and boys between the ages of 7 and 40 are consistently identified as the primary participants in illegal hunting, dogs as the favored hunting tool, and desire for wild meat as a primary motivator (Infield 1988; Kaschula and Shackleton 2009, 2012; Manqele et al. 2018). In two studies, over three-quarters of respondents reported hunting primarily in social groups with other men and their dogs (Kaschula and 
Shackleton 2009; Manqele et al. 2018). The social dimensions of hunting point to motivation beyond protein alone. Dlamini (2005:86) reports that informants in KwaZulu-Natal emphasized that "we do not hunt because we are hungry," but rather from the "need to fulfill this cultural and recreational activity." Dlamini (2005:87) reported that another informant stated that inability to hunt

lowers the community dignity as well as attachment to tradition, loss of contact with nature and so on. Now that we cannot practice our tradition and culture, instead we watch foreign safari hunters slaughtering our wildlife resources; we are now a weak society.

These perspectives illuminate the wider significance of hunting with dogs, tethered to a dual inheritance: a deep cultural history alongside a more recent history of dispossession. Hunters interviewed by Kepe et al. (2001) invoke the concept of ukuloja, a Zulu term for locally legitimate stealing of a resource based on historical claim to it. One hunter asks: "how can someone who does not live here with us refer to us as poachers just because we harvest our own resources? We are just good hunters and above all, we have kept these wildlife for many years" (Hebinck 2018:279).

These voices point to aspects of illegal hunting in South Africa that have not been adequately investigated but are crucial to addressing challenges in community-based conservation. Holmes (2007) posits that when small actors practice banned traditions, these acts contain wider symbolic meaning, a form of resistance in a political system that does not regard one's own traditions as legitimate. Top-down restrictions in African conservation have had significant collateral effects, leading to more hunting being classified as illegal by being too restrictive of traditional cultural practices ('t Sas-Rolfes 2017:3). Despite increased interest in probing the role of culture and structural inequality in African conservation, "much of this line of inquiry is nascent and unacknowledged" when it comes to illegal hunting ('t Sas-Rolfes 2017:3). Duffy et al. (2016) argue that poverty alone does not capture the motivation behind hunting, but that these practices are also driven by demand for satisfaction of cultural needs, enactment of values, and links to identity and agency that subsistence alone does not encompass. Contemporary conservation cannot succeed without earnest inclusion of community values and perceptions. Ethnographic research on illegal hunting offers a necessary path toward remedying this knowledge gap and addressing challenges to community-based conservation.

After over a century of restriction, illegal hunting with dogs occupies a juncture where issues of land use, conservation, and livelihood meet. The relative lack of hunters' voices in the academic literature points to the need for ethnographic approaches rooted in environmental history to grapple with the drivers of illegal hunting with dogs. Untangling the conflicting narratives around illegal hunting will require close examination of its emic threads: into the woven history of dispossession and restriction of cultural traditions, which extend from the past to the present.

\section{Acknowledgments}

Thank you to Dr. Rob Quinlan for the guidance, encouragement, and editing assistance. Thank you to the anonymous reviewers for their constructive feedback and suggestions for improving this manuscript.

\section{Declarations}

Permissions: None declared.

Sources of funding: None declared.

Conflicts of Interest: None declared.

\section{References Cited}

Couzens, E. 2007. Is Conservation a Viable Land Usage: Issues Surrounding the Sale of Ivory by Southern African Countries. In Land Use Law for Sustainable Development, edited by N. Chalifour, P. Kameri-Mbote, L. H. Lye, and J. Nolon, pp. 27-44. Cambridge University Press, Cambridge, MA.

Couzens, E., and A. Blackmore. 2010. A Millennium Overturned: The Long History in England and South Africa of Laws against Hunting with Dogs, and Recent Statutory Changes in the Province of KwaZulu-Natal. In Stella Iuris: Celebrating 100 Years of Teaching Law in Pietermaritzburg, edited by M. Kidd and S. Hoctor, pp. 298-321. Juta, Claremont, South Africa.

Dlamini, Z. 2005. Creating Stakeholders in Community-Based Natural Resource Management Through Traditional Hunting: A Comparative Study of Inhluzani Farm and Mpembeni Community Game Reserve in KwaZulu-Natal. Master's Thesis, School of Environmental Sciences, University of 
KwaZulu-Natal, Durban, South Africa. Available from University of KwaZulu-Natal Research Space.

Duffy, R., F. St John, B. Büscher, and D. Brockington. 2016. Toward a New Understanding of the Links between Poverty and Illegal Wildlife Hunting. Conservation Biology 30:14-22. DOI:10.1111/ cobi.12622.

Grey-Ross, R., C. T. Downs, and K. Kirkman. 2010. An Assessment of Illegal Hunting on Farmland in KwaZulu-Natal, South Africa: Implications for Oribi (Ourebia Ourebi) Conservation. South African Journal of Wildlife Research 40:43-52. DOI:10.3957/056.040.0104.

Hebinck, P. 2018. Poaching: Between Conservation from Below, Livelihoods, and Resistance. In Nature Conservation in Southern Africa: Morality and Marginality: Towards Sentient Conservation?, edited by J. B. Gewald, M. Spierenburg, and H. Wels, pp. 257-292. Brill, Boston, MA.

Holmes, G. 2007. Protection, Politics and Protest: Understanding Resistance to Conservation. Conservation and Society 5:184-201.

Infield, M. 1988. Attitudes of a Rural Community towards Conservation and a Local Conservation Area in Natal, South Africa. Biological Conservation 45:21-46. DOI:10.1016/0006-3207(88)90050-x.

Kaschula, S., and C. Shackleton. 2009. Quantity and Significance of Wild Meat Off-Take by a Rural Community in the Eastern Cape, South Africa. Environmental Conservation 36:192-200. DOI:10.1017/s0376892909990282.

Kaschula, S., and C. Shackleton. 2012. How Do HIV and AIDS Impact the Use of Natural Resources by Poor Rural Populations? The Case of Wild Animal Products. South African Journal of Science 108:1-9. DOI:10.4102/sajs.v108i1/2.549.

Kepe, T., B. Cousins, and S. Turner. 2001. Resource Tenure and Power Relations in Community Wildlife: The Case of the Mkambati Area, South Africa. Society \& Natural Resources 14:911-925. DOI:10.1080/089419201753242814.
KwaZulu-Natal Nature Conservation Management Amendment Act (No. 5 of 1999). Food and Agriculture Organization of the United Nations FAOLEX Database [web page]. Available at: http://extwprlegs1.fao.org/docs/pdf/saf93097.pdf. Accessed on November 30, 2019.

Manqele, N. S., J. A. Selier, T. R. Hill, and C. T. Downs. 2018. Drivers of the Illegal Hunting of Serval (Leptailurus Serval) and Oribi (Ourebia Ourebi) in the KwaZulu-Natal Midlands, South Africa. African Journal of Wildlife Research 48:023004. DOI:10.3957/056.048.023004.

Pasmans, T., and P. Hebinck. 2017. Rural Development and the Role of Game Farming in the Eastern Cape, South Africa. Land Use Policy 64:440450. DOI:10.1016/j.landusepol.2017.03.010.

Snijders, D. 2012. Wild Property and Its Boundaries on Wildlife Policy and Rural Consequences in South Africa. The Journal of Peasant Studies 39:503-520. DOI:10.1080/03066150.2012.667406.

't Sas-Rolfes, M. 2017. African Wildlife Conservation and the Evolution of Hunting Institutions. Environmental Research Letters 12:115007. DOI:10.1088/1748-9326/aa854b.

Tropp, J. 2002. Dogs, Poison, and the Meaning of Colonial Intervention in the Transkei, South Africa. The Journal of African History 43:451-472. DOI:10.1017/s0021853702008186.

Van Sittert, L., and S. Swart, eds. 2008. Canis Africanis: A Dog History of South Africa. Brill, Boston, MA.

Warchol, G., and B. Johnson. 2009. Wildlife Crime in the Game Reserves of South Africa: A Research Note. International Journal of Comparative and Applied Criminal Justice 33:143-154.

DOI:10.1080/01924036.2009.9678800. 